\title{
Cadmium and zinc in acid tropical soils: III. response of cocoa seedlings in a greenhouse experiment
}

\begin{abstract}
Many phosphate rock (PR) materials used as direct application of fertilizer containing variable amounts of heavy metals, such as cadmium $(\mathrm{Cd})$ and zinc $(\mathrm{Zn})$. The effect of $\mathrm{Cd}$ and $\mathrm{Zn}$ addition to unlimed and limed $(\mathrm{pH}$ 5.5) soils on the growth of cocoa seedlings (Theobroma cacao L.) U1T1 X NA33 hybrid was conducted in the field at Kunak, Tawau, Sabah. Cadmium [as $\mathrm{Cd}(\mathrm{SO} 4) \cdot 8 \mathrm{H} 2 \mathrm{O}$ ] and $\mathrm{Zn}$ [as $\mathrm{Zn}(\mathrm{SO} 4) \cdot 7 \mathrm{H} 2 \mathrm{O}$ ] were added in solution form at $0,2.8,14$, and $28 \mathrm{~kg} \mathrm{Cd}$ ha-1 year-1 and $0,28,140$, and $280 \mathrm{~kg} \mathrm{Zn} \mathrm{ha-1} \mathrm{year-1,}$ respectively, to each of three top $(0-15 \mathrm{~cm})$ soils from Katai (Typic Hapludult, Koyah (Oxic Dystropept), and Table (Typic Hapludox). At harvest, plant growth parameters, plant height and plant dry-matter yield, were measured. Cadmium and $\mathrm{Zn}$ contents were partitioned into plant roots, stems, leaves, and in the soils. Plant height and dry-matter yield of cocoa differed markedly between levels of $\mathrm{Cd}$ and $\mathrm{Zn}$ added to unlimed and limed soils. A positive plant growth response of the added $\mathrm{Cd}$ and $\mathrm{Zn}$ was clearly apparent in the Table soil as compared to the Katai and Koyah soils, A significant increase $(\mathrm{p}<0.05)$ in all plant growth parameters was obtained at the concentration of $2.8 \mathrm{mg} \mathrm{Cd} \mathrm{kg-1} \mathrm{and} 28 \mathrm{~kg} \mathrm{Zn} \mathrm{kg-1}$ added to the limed soils. In contrast, a significant $(\mathrm{p}<0.05)$ reduction of the parameter measured was obtained in unlimed soils at a concentration of more than $14 \mathrm{mg} \mathrm{Cd} \mathrm{kg-1}$ and $140 \mathrm{mg} \mathrm{Zn} \mathrm{kg-1} \mathrm{of} \mathrm{soil.}$ Analysis of the $\mathrm{Cd}$ and $\mathrm{Zn}$ contents showed that substantial amounts of these elements accumulated in the leaves, stems, and roots of cocoa, while very little were present in the soils. Liming the soils before the addition of $\mathrm{Cd}$ and $\mathrm{Zn}$ significantly $(\mathrm{p}<0.05)$ reduced the amount of metal accumulation in these plant parts.
\end{abstract}

Keyword: Cadmium; Zinc; Cocoa seedlings; Greenhouse; Acid tropical soils 